This PDF is a selection from a published volume from the National Bureau of Economic Research

Volume Title: Trade in Services in the Asia Pacific Region, NBER East Asia Seminar on Economics (EASE), Volume 11

Volume Author/Editor: Takatoshi Ito and Anne O. Krueger, editors

Volume Publisher: University of Chicago Press

Volume ISBN: 0-226-38677-5

Volume URL: http://www.nber.org/books/ito_03-1

Conference Date: June 22-24, 2000

Publication Date: January 2003

Title: Liberalization of Trade in Services and Productivity Growth in Korea

Author: Jong-Il Kim, June-Dong Kim

URL: http://www.nber.org/chapters/c10159 


\title{
Liberalization of Trade in Services and Productivity Growth in Korea
}

\author{
Jong-Il Kim and June-Dong Kim
}

\subsection{Introduction}

Korea's economic development over the past twenty five years has been based on industrialization, with priority being given to the manufacturing sectors at the expense of services. However, since the financial crisis of late 1997, the importance of the service sector has been increasingly recognized, and comprehensive reforms in the service sector were recommended in order to restore the crisis-ridden economy to its previous growth path (McKinsey 1998).

The liberalization of services can bring potential gains in productivity in service sectors that are subject to technology transfers and economies of scale. These are similar to the productivity effects of foreign direct investment (FDI) in the manufacturing sector, because a significant portion of service supplies occurs through FDI. Various studies show positive evidence of the productivity spillovers of FDI (Caves 1974; Globerman 1979; Blomstrom and Persson 1983; Borensztein, de Gregorio, and Lee 1998). Foreign investment may also raise productivity by enhancing competition. Based on an analysis of approximately 670 U.K. companies, Nickell (1996) showed that competition, as measured by increased numbers of competitors or by lower levels of rents, is associated with a significantly higher rate of total factor productivity growth. Using firm-level panel data of U.S. automobile component manufacturers, Chung, Mitchell, and Yeung (1994) found that productivity gains among the host country suppliers largely stem from the increase in competition created by FDI.

Anecdotal evidence shows that foreign-invested firms may raise produc-

Jong-Il Kim is an associate professor of economics at Dongguk University, and June-Dong $\mathrm{Kim}$ is a research fellow at the Korea Institute for International Economic Policy. 
tivity by spinning out skilled workers, providing technical guidance to subcontractors, bringing in new capital goods and technology, introducing advanced management know-how, conducting in-house research and development, and enhancing competition (Kim and Hwang 2000, 272). Most of these channels of raising productivity through FDI apply to both the manufacturing and service sectors.

Moreover, the liberalization of trade in services may result in improved productivity in other sectors, including manufacturing, due to the resulting access to a broader variety, better quality, and lower cost of inputs. Using a model of increasing returns due to specialization, Rivera-Batiz and RiveraBatiz (1992) argued that FDI in the business service sector stimulates specialization and raises the productivity of the industry that uses them. Markusen (1989) also demonstrated that allowing trade in producer services is superior to allowing trade in final goods only, due to the complementarity between domestic and foreign producer services.

This paper investigates the changes in productivity growth rates of Korean service and manufacturing subsectors in relation to the liberalization of trade in services. Since Korea underwent accelerated liberalization of the service sector in the 1990s, we try to examine whether the service subsectors that were liberalized and the manufacturing subsectors that use liberalized services as inputs experienced productivity gains in this period.

This paper is organized as follows: Section 6.2 reviews the evolution of liberalization in services in Korea as well as the recent trends of trade in services. Section 6.3 illustrates the case of distribution services, which were liberalized almost completely in the 1990s. Changes in productivity in the service and manufacturing subsectors are explored in section 6.4 with a tabulation of the trends of labor and total factor productivity. We then investigate whether liberalized service subsectors posted relatively higher productivity growth and contributed to productivity gains in the manufacturing subsectors. Concluding remarks and policy implications are provided in section 6.5.

\subsection{Evolution of Services Liberalization and Recent Trends of Trade in Services}

\subsubsection{Evolution of Services Liberalization}

Unlike the manufacturing sector, in which FDI had been liberalized since the early 1980s, much of the services liberalization has only taken place since the mid-1990s. Table 6.1 shows that the Korean government has liberalized 154 business categories (at the Korean standard industrial classification [KSIC] five-digit level) in the service sector, completely or partially, since 1993. Many of these service subsectors were liberalized as a result of 
Korea's FDI Liberalization, 1993-2000 (as of May 2000)

\begin{tabular}{lcrrrrrrrrr}
\hline & & \multicolumn{8}{c}{ Liberalized } & \\
\cline { 3 - 9 } Classification & Total & 1993 & 1994 & 1995 & 1996 & 1997 & 1998 & 1999 & 2000 & $\begin{array}{c}\text { Remaining } \\
\text { Restricted }\end{array}$ \\
\hline Manufacturing & 585 & 2 & 1 & 0 & 6 & 1 & 2 & 2 & 0 & 0 \\
Services & 495 & 9 & 23 & 42 & 39 & 16 & 20 & 3 & 2 & $2(22)$ \\
Others & 68 & 5 & 6 & 2 & 4 & 10 & 0 & 0 & 1 & $2(2)$ \\
Total & $1,148^{\mathrm{a}}$ & 16 & 30 & 44 & 49 & 27 & 22 & 5 & 3 & $4(24)$ \\
\hline
\end{tabular}

Source: Ministry of Finance and Economy, Five-Year Foreign Investment Liberalization Plan (various years), and Ministry of Commerce, Industry, and Energy, Consolidated Public Notice for Foreign Investment (May 2000).

Notes: The business categories are at the Korean Standard Industrial Classification (KSIC) five-digit level. "Others" denotes agriculture, fisheries and mining. "Liberalized" includes both complete and partial liberalization. The number of partially restricted business categories is in parentheses.

${ }^{a}$ Business categories that include government services and nonprofit organizations, where FDI is prohibited by domestic law, are not counted.

the Uruguay Round negotiations and Korea's accession to the Organization for Economic Cooperation and Development (OECD) in 1996. Additional liberalization took place after Korea suffered from economic crisis in 1997. In 1998, as a way of attracting more foreign investment and enhancing efficiency, the Korean government accelerated the liberalization of the service sector beyond the level of its OECD and World Trade Organization (WTO) commitments.

Comparison of service subsectors in which FDI was restricted as of January 1990 (table 6A.1) with those as of November 1997 (table 6A.2) shows that distribution services, business services, entertainment and recreational services, and other personal services have been liberalized since 1990. Also, transportation services, financial services, and telecommunication services were partially liberalized during this period.

More drastic liberalization has been implemented since the financial crisis of late 1997. Twenty-two business categories, most of which are in the service sector, including real estate rental and sales, land development, waterworks, and investment companies, fully opened in 1998. By May 1999, three more service business categories, the publishing of books, outer maritime transportation, and the operation of casinos, fully opened. Furthermore, existing ceilings on foreign equity ratios were raised in 1999 in six business categories: newspaper publishing, cable broadcasting, wire telegraph and telephone, and wireless telegraph and telephone.

As a result, only twenty four business categories in the service sector remained to be completely liberalized as of May 2000. Among them, radio and television broadcasting are the two categories in which FDI is wholly restricted. Foreign direct investment in twenty two business categories, including the publishing of newspapers, coastal water transport, air trans- 
Table 6.2 Service Business Categories in which FDI is Restricted, Korea (as of May 2000)

\begin{tabular}{l|l}
\hline Wholly Restricted & Partially Restricted \\
\hline Radio broadcasting & Wholesale of meats \\
Television broadcasting & Publishing (newspapers, periodicals) \\
& Processing of nuclear fuel \\
& Electric power generation \\
& Coastal water transport (passenger, freight) \\
& Air transport (scheduled, non-scheduled) \\
& Telecommunications (leased line, wired, \\
mobile, cellular, resellers, other) \\
& Domestic banking (special banking) \\
& Investment trust companies \\
& Program supplying \\
& Cable broadcasting, satellite broadcasting \\
& News agency activities \\
& Radioactive waste disposal \\
\hline
\end{tabular}

Source: Ministry of Commerce, Industry, and Energy, Consolidated Public Notice for Foreign Investment (May 2000).

port, telecommunications, investment trust companies, and electric power generation, are partially restricted (table 6.2). ${ }^{1}$

\subsubsection{Recent Trends of Trade in Services}

The service sector is gaining importance in the Korean economy, with its share of GDP and employment having increased from 43.9 percent and 39.5 percent in 1980 to 52.7 percent and 59.8 percent in 1998, respectively. However, the share of the service sector in the domestic economy is lower than that of the United States, Singapore, and Japan, where its portion of the GDP in 1996 was 74.1 percent, 70.9 percent, and 64.4 percent, respectively.

Table 6.3 shows Korea's trade in services by mode of supply in the 1990s. The sum of exports and imports, of cross-border supply, which is measured by commercial services in balance of payments (BOP), except for tourism, increased from about $\$ 16$ billion in 1991 to $\$ 39.6$ billion in 1998. Trade in services by the three modes of supply (cross-border supply, consumption abroad, and movement of natural persons), except commercial presence, increased from $\$ 22.8$ billion in 1991 to $\$ 49$ billion in 1998. In 1998, the total amount of Korea's trade in services, except commercial presence, was almost 20 percent of the amount of trade in goods. The share in the world's total trade in services, except commercial presence, also rose from 1.2 percent in 1991 to 1.8 percent in 1998.

Table 6.4 reveals that a significant increase in trade in services has occurred through commercial presence since the 1980s. Foreign direct investment inflows in services increased from $\$ 1.6$ billion in $1982-90$ to $\$ 6.3$ billion in

1. Even though FDI in legal services is not restricted, foreign lawyers are not allowed to practice unless they acquire a domestic license. 
Trade in Services by Modes of Supply, Korea: 1991, 1995, 1998

(US\$ millions)

\begin{tabular}{|c|c|c|c|c|c|c|}
\hline & \multicolumn{2}{|c|}{1991} & \multicolumn{2}{|c|}{1995} & \multicolumn{2}{|c|}{1998} \\
\hline & Exports & Imports & Exports & Imports & Exports & Imports \\
\hline Cross-border supplya & 7,158 & 8,953 & 17,677 & 19,465 & 18,647 & 21,053 \\
\hline Transportation & 3,873 & 4,897 & 9,272 & 9,645 & 10,204 & 8,983 \\
\hline Communications & 353 & 204 & 561 & 642 & 656 & 1,133 \\
\hline Consumption abroad ${ }^{\mathrm{b}}$ & 2,856 & 3,214 & 5,150 & 6,341 & 5,933 & 2,898 \\
\hline Commercial presence & n.a. & n.a. & n.a. & n.a. & n.a. & n.a. \\
\hline Movement of natural persons ${ }^{c}$ & 604 & 54 & 774 & 132 & 446 & 42 \\
\hline Total & $\begin{array}{c}10,618 \\
(1.2)\end{array}$ & $\begin{array}{c}12,221 \\
(1.3)\end{array}$ & $\begin{array}{c}23,601 \\
(1.8)\end{array}$ & $\begin{array}{c}25,938 \\
(2.0)\end{array}$ & $\begin{array}{c}25,026 \\
(1.8)\end{array}$ & $\begin{array}{c}23,993 \\
(1.7)\end{array}$ \\
\hline
\end{tabular}

Source: International Monetary Fund, Balance of Payments Statistics Yearbook (1999).

Note: Percentage shares in the world's trade in services are in parentheses.

${ }^{a}$ BOP commercial services minus travel.

${ }^{\mathrm{B}} \mathrm{BOP}$ travel.

'BOP compensation of employees.

Table 6.4

FDI Inflows in Service Subsectors, Korea: 1962-99 (\%)

\begin{tabular}{lccrrr}
\hline Subsector & $1962-81$ & $1982-90$ & $1991-95$ & $1996-97$ & $1998-99$ \\
\hline Total FDI in services & & & & & \\
$\quad$ (US\$ millions) & 412.2 & $1,600.2$ & $2,078.7$ & $2,213.1$ & $6,330.9$ \\
Electricity and gas & 0 & 0 & 26.1 & 0 & 378.7 \\
Construction & 10.4 & 40.1 & 21.4 & 79.8 & 9.6 \\
Wholesale and retail & 0 & 20.1 & 103.4 & 586.6 & 956.7 \\
Trading & 0.4 & 55.5 & 394.7 & 306.5 & 336.1 \\
Restaurants & 0 & 4.2 & 60.2 & 7.1 & 9.4 \\
Hotels & 206.0 & 956.9 & 362.3 & 211.4 & 64.5 \\
Transportation & 28.7 & 9.6 & 9.9 & 150.2 & 9.4 \\
Financial & 109.7 & 384.9 & 710.3 & 480.8 & $2,292.9$ \\
Insurance & 3.0 & 77.3 & 158.0 & 23.2 & 407.9 \\
Real Estate & 0 & 0 & 1.8 & 0.1 & 33.0 \\
Others & 53.9 & 51.4 & 230.5 & 367.4 & $1,832.5$ \\
Total FDI into Korea & & & & & $15,489.7$ \\
$\quad$ (US\$ millions) & $1,477.8$ & $4,385.1$ & $5,057.2$ & $5,394.2$ & \\
\hline
\end{tabular}

Source: Ministry of Commerce, Industry, and Energy, Trends in Foreign Direct Investment (January 31,2000 ).

Note: Based on actual investment.

1998-99. Hotels were the largest recipients through the 1980s. In the 1990s, FDI increased remarkably in distribution services (wholesale and retail), transportation services, financial services, and other services, which are mainly composed of telecommunication and business services. Foreign direct investment in distribution services increased from \$20.1 million in 1982-90 to $\$ 586.6$ million in 1996-97. Foreign direct investment in transportation ser- 
Table 6.5

Comparison of Productivity in Distribution Services, Korea and Japan: 1994 (US\$ thousands)

\begin{tabular}{lcrrrr}
\hline & \multicolumn{2}{c}{ Wholesale } & & \multicolumn{2}{c}{ Retail } \\
\cline { 2 - 3 } \cline { 6 - 7 } & Korea & Japan & & Korea & Japan \\
\hline Sales per establishment & 693 & 11,724 & & 117.8 & 935.2 \\
Sales per employee & 170 & 1,099 & & 57.8 & 190.0 \\
\hline
\end{tabular}

Source: National Statistical Office, R.O.K., Annual Report on the Survey of Wholesale and Retail Trade as of 1994, and Ministry of Industry and Trade, Japan, Annual Statistical Report of Commerce in 1994.

Note: Applied exchange rates are US $1 \$=716.4$ Korean won; US $1 \$=102.18$ Japanese yen.

vices also increased, from $\$ 9.9$ million in 1991-95 to \$150.2 million in 199697. Foreign direct investment in financial services and other services experienced a sharp increase after the financial crisis. Foreign direct investment in financial services increased from $\$ 480.8$ million in 1996-97 to \$2.3 billion in 1998-99. The increase in FDI in other services was almost sixfold during the same period, from \$367.4 million in 1996-97 to \$1.8 billion in 1998-99.

\subsection{The Experience of Liberalization in Distribution Services}

In this section, we focus on the distribution sector, which experienced significant liberalization during the 1990s, to illustrate how liberalization affects the productivity of a specific sector.

Distribution services had been one of the least developed sectors in Korea up to the mid-1990s, along with financial services. Mom-and-pop stores having fewer than five employees accounted for approximately 80 percent of Korea's $\$ 116$ billion retail market in 1996. The productivity of Korea's wholesale and retail service sector, in terms of sales per establishment or sales per employee, was far below that of Japan in 1994 (table 6.5).

We may attribute the low productivity of Korean distribution services to the regulations on zoning and land development and to the restrictions on FDI. The regulations on zoning and land development reduced the availability of land, limiting the scale of operation, and the restrictions on FDI prevented exposure to foreign best practices. ${ }^{2}$

However, a remarkable transformation has taken place in Korea's distribution industry since the government lifted some of the restrictions that kept foreign service suppliers out of the country before 1996 (table 6.6). ${ }^{3}$ In

2. In terms of deregulation of zoning, the semiagricultural and forest areas were redefined to allow retail stores occupying less than 30,000 square meters to be built in 1993. In 1996, large discount retailers under 10,000 square meters were allowed to do business in the green areas, where development is regulated by the law. The objective was to promote discount stores (Mckinsey 1998).

3. In most of the service subsectors, the Korean government implemented domestic deregulation and external liberalization almost simultaneously. It used external commitment to liberalization in reducing any opposition or resistance to domestic deregulation or implemented domestic 
Table 6.6

Liberalization of Distribution Services, Korea: 1989-2000

\begin{tabular}{cl}
\hline Year & \multicolumn{1}{c}{ Liberalization Measures } \\
\hline 1989 & $\begin{array}{l}\text { Allow FDI in wholesale of medicine } \\
\text { Expand permissible imports by branches of foreign companies } \\
\text { Allow FDI in retailing, up to } 10 \text { stores of } 1,000 \mathrm{~m}^{2} \text { or less for each foreign-invested } \\
\text { company }\end{array}$ \\
1991 & $\begin{array}{l}\text { Expand store and space-related limits to } 20 \text { stores of } 3,000 \mathrm{~m}^{2} \text { or less for each } \\
\text { company }\end{array}$ \\
1996 & $\begin{array}{l}\text { Eliminate requirements on the number of stores and space (allowed establishment } \\
\text { of hyper-markets) }\end{array}$ \\
1997 & $\begin{array}{l}\text { Liberalize } 5 \text { business categories, including commodity chains, and the retailing of } \\
\text { meat }\end{array}$ \\
1998 & $\begin{array}{l}\text { Liberalize } 10 \text { business categories, including general trading and the retailing of } \\
\text { Abolish economic needs tests on department stores and shopping centers }\end{array}$ \\
2000 & $\begin{array}{l}\text { Liberalize operation of gas stations } \\
\text { Allow FDI in the wholesaling of meat }\end{array}$ \\
\hline
\end{tabular}

Source: Ministry of Commerce, Industry, and Energy, Department of Distribution.

Table 6.7

Trends in the Establishment of Hyper-markets in Korea: 1997-2000

\begin{tabular}{|c|c|c|c|c|c|}
\hline \multirow[b]{2}{*}{ Name } & \multirow[b]{2}{*}{ Year of Entry ${ }^{a}$} & \multicolumn{4}{|c|}{ Number of Stores } \\
\hline & & 1997 & 1998 & 1999 & 2000 \\
\hline Carrefour & 1996 & 3 & 6 & 11 & 20 \\
\hline Wal-Mart & 1996 & 4 & 4 & 5 & 10 \\
\hline Costco & 1998(1994) & 2 & 3 & 3 & 5 \\
\hline Promodes & 1999 & - & - & 2 & 5 \\
\hline Tesco & 1999(1997) & 1 & 1 & 2 & 7 \\
\hline Total for foreign companies ${ }^{b}$ & - & $\begin{array}{c}10 \\
(15 \%)\end{array}$ & $\begin{array}{c}14 \\
(16 \%)\end{array}$ & $\begin{array}{c}23 \\
(20 \%)\end{array}$ & $\begin{array}{c}47 \\
(29 \%)\end{array}$ \\
\hline Total for Korean companies ${ }^{b}$ & - & $\begin{array}{c}55 \\
(85 \%)\end{array}$ & $\begin{array}{c}74 \\
(84 \%)\end{array}$ & $\begin{array}{c}92 \\
(80 \%)\end{array}$ & $\begin{array}{c}117 \\
(71 \%)\end{array}$ \\
\hline Total & - & 65 & 88 & 115 & 164 \\
\hline
\end{tabular}

Source: Korean Association of Retailers, Management Revolution in 21st-Century Asian Retailing (December 27, 1999).

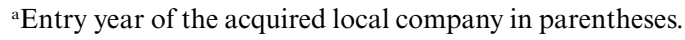

${ }^{\mathrm{b}} \mathrm{Shares}$ in total number of stores in parentheses.

particular, store and space-related limits on retailing were eliminated for both domestic and foreign retail firms. As a result, a number of large-sized discount stores or hypermarkets have been established by both domestic and foreign firms since 1996. The total number of hypermarket stores reached 164 in 2000, and almost 30 percent of them have been established by foreign firms (table 6.7).

deregulation to help domestic firms establish market position before foreign penetration. Hence, it is difficult to differentiate the impact of domestic deregulation from external liberalization. 
The increasing number of hypermarkets is changing the manufacturerdominated structure of the Korean retail industry, which had deterred productivity improvements and price competition. The increased buying power of the hypermarkets puts price determining in the hands of retailers rather than manufacturers, leading to price competition. Foreign retail firms also transferred advanced techniques in merchandising and inventory management as well as new technologies such as point of sales (POS) systems.

Table 6.8 presents the change in number of establishments per 1,000 res-

Table 6.8 Trends in the Sizes of Establishments in Distribution Services, Korea and Japan: 1982-98

\begin{tabular}{|c|c|c|c|c|}
\hline \multirow[b]{2}{*}{ Year } & \multicolumn{2}{|c|}{ Korea } & \multicolumn{2}{|c|}{ Japan } \\
\hline & Wholesale & Retail & Wholesale & Retail \\
\hline & \multicolumn{4}{|c|}{ Number of Establishments per 1000 Residents } \\
\hline 1982 & 1.2 & 13.8 & 3.3 & 14.5 \\
\hline 1985 & - & - & 3.1 & 13.5 \\
\hline 1986 & 1.7 & 15.5 & - & - \\
\hline 1988 & 1.9 & 16.0 & - & - \\
\hline 1990 & 2.1 & 16.6 & 3.8 & 12.8 \\
\hline 1992 & 2.6 & 16.9 & - & - \\
\hline 1994 & 2.7 & 17.0 & - & - \\
\hline 1996 & 3.2 & 16.9 & - & - \\
\hline \multirow[t]{2}{*}{1998} & 3.1 & 15.6 & - & - \\
\hline & \multicolumn{3}{|c|}{ Workers per Establishment } & \\
\hline 1982 & 3.8 & 1.7 & 9.3 & 3.7 \\
\hline 1985 & - & - & 9.4 & 3.9 \\
\hline 1986 & 5.0 & 1.9 & - & - \\
\hline 1988 & 5.4 & 1.9 & - & - \\
\hline 1990 & 5.5 & 1.9 & - & - \\
\hline 1992 & 4.7 & 1.9 & - & - \\
\hline 1994 & 5.1 & 2.0 & - & - \\
\hline 1996 & 4.3 & 2.1 & - & - \\
\hline \multirow[t]{2}{*}{1998} & 4.2 & 2.0 & - & - \\
\hline & \multicolumn{3}{|c|}{ Floor Space per Establishment $\left(\mathrm{m}^{2}\right)$} & \\
\hline 1982 & - & - & - & 55.4 \\
\hline 1985 & - & - & - & 58.0 \\
\hline 1986 & - & - & - & - \\
\hline 1988 & - & - & - & - \\
\hline 1990 & - & - & - & - \\
\hline 1992 & 75.7 & 35.6 & - & - \\
\hline 1994 & 92.7 & 38.7 & - & - \\
\hline 1996 & 129.4 & 45.8 & - & - \\
\hline 1998 & 136.4 & 52.8 & - & - \\
\hline
\end{tabular}

Sources: The data on Korea are constructed from various issues of the Annual Report on the Survey of Wholesale and Retail Trade, published by the Korean National Statistical Office. The data on Japan are from Ito and Maruyama (1991) and Anwar and Taku (1993).

Note: Dashes indicate that data are not available. 
idents, workers per establishment, and floor space per establishment since 1982. The Korean distribution sector has experienced growth in terms of number of establishments as well as the size of establishments. Particularly, the number of wholesale establishments has grown quickly from 1.2 per 1,000 residents in 1982 to 3.1 in 1998 . The number of retail stores reached 16.6 per 1,000 residents in 1990, far surpassing Japan. Although the Japanese distribution sector is accused of inefficiency due to the presence of many small establishments, the Korean distribution sector may be regarded as worse, with much smaller establishments in terms of size. ${ }^{4}$ However, in the mid-1990s, the number of establishments in retailing began to decline, while the size continued to grow. During this period, the domestic retailing sector began to be exposed to foreign competition as foreign firms started to enter the market, as shown in table 6.7.

Figure 6.1 decomposes the growth of sales into the growth of the number of establishments and the growth of sales per establishment. The total amount of sales has grown steadily except for the period 1996-98, when Korea fell into a severe recession due to the financial crisis. In wholesale services, the opening of new establishments contributed to the growth of sales. However, in retail services, the growth of sales came largely from the growth of sales per establishment. Particularly, in contrast to the wholesale sector, opening of new retail stores slowed down in the 1990s, and the number of establishments even declined from 1996 to 1998.

Figures 6.2 and 6.3 show sales per employee and sales per establishment. The sales per employee and sales per establishment, which are widely used as measures of productivity and efficiency of the distribution system, show that the productivity of the Korean distribution sector has continually increased over time. Sales per both worker and establishment increased notably in 1996, which may be a result of the service liberalization and resulting FDI inflow. However, we have to wait to see whether this trend will continue after the economy recovers from the deep recession of 1998.

Figure 6.4 breaks down the sales per employee of retail stores according to their size. It shows that sales per employee of large retail stores, with five or more employees, recorded a noticeable increase in 1998, whereas sales per employee of small retail stores, with fewer than five employees, have been stagnant since 1996. This may be because liberalization of the retail sector brought about enhanced competition in the large-sized retail stores through the establishment of hypermarkets by foreign retailers. The role of liberalization in enhancing competition may be ascertained by the lower price margins of the supermarkets and department stores, from 17.8 percent and 24.2 percent in 1995 to 13.6 percent and 21.7 percent in 1998, re-

4. For a discussion of the efficiency of the Japanese distribution system, see Ito and Maruyama (1991) and Anwar and Taku (1993). 


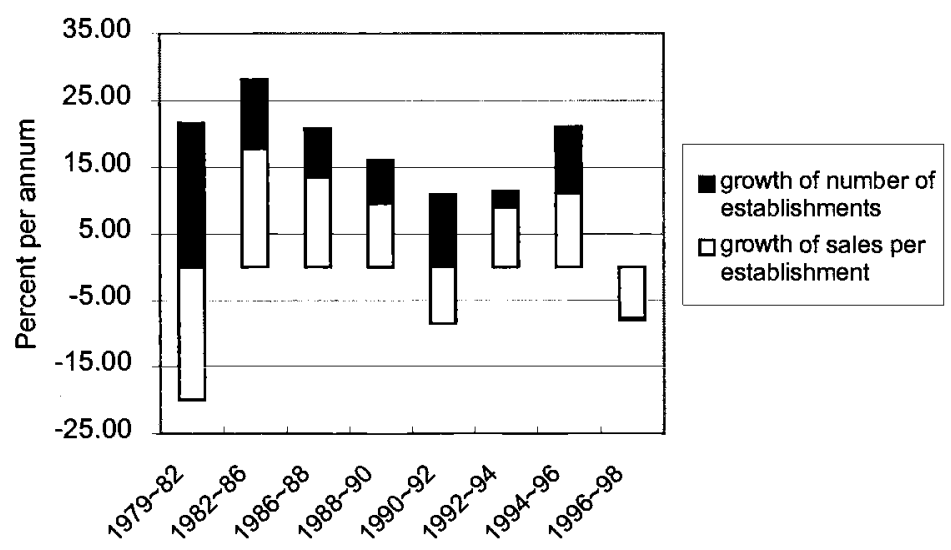

Retail

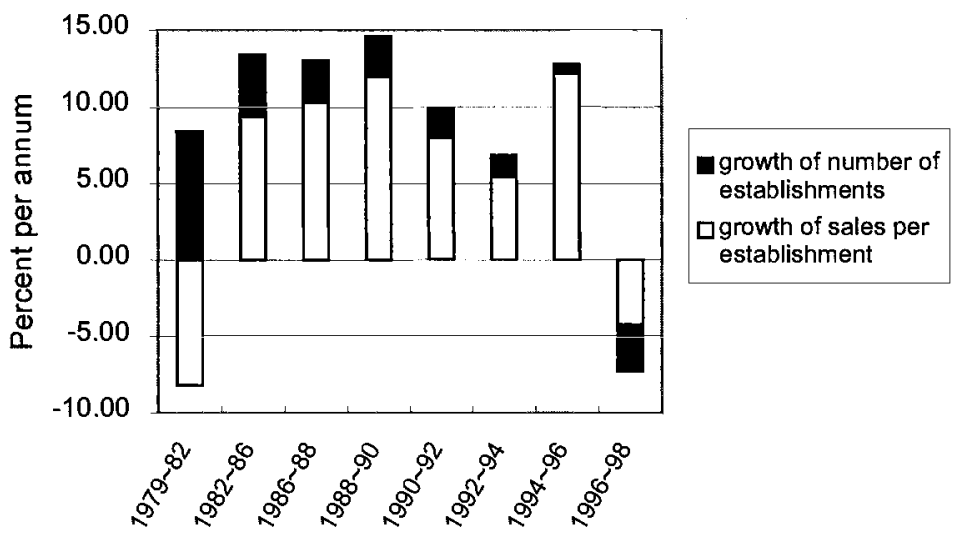

Fig. 6.1 Decomposition of sales growth in distribution services, Korea (1979-98)

Source: National Statistical Office, Republic of Korea, "Annual Report on the Survey of Wholesale and Retail Trade," various years.

Note: The amount of sales is deflated using the producer and consumer price index for wholesale and retail, respectively.

spectively (table 6.9). This reveals that supermarkets and department stores face direct challenges from foreign competitors.

In sum, a rough observation of the measures of efficiency points to enhanced productivity of the Korean distribution services with liberalization in the 1990s, although we cannot provide definite evidence due to the limited data. Particularly, the inflow of FDI with the opening of hypermarkets 


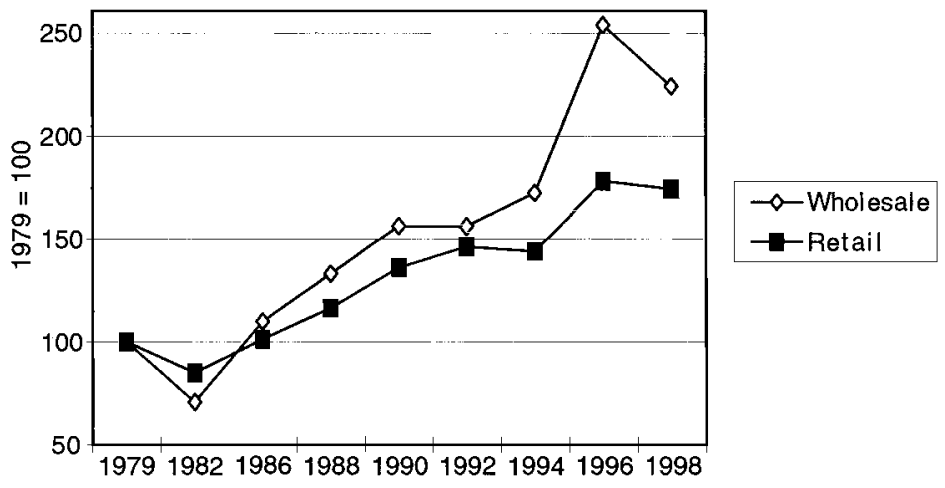

Fig. 6.2 Sales per employee in distribution services, Korea (1979-98)

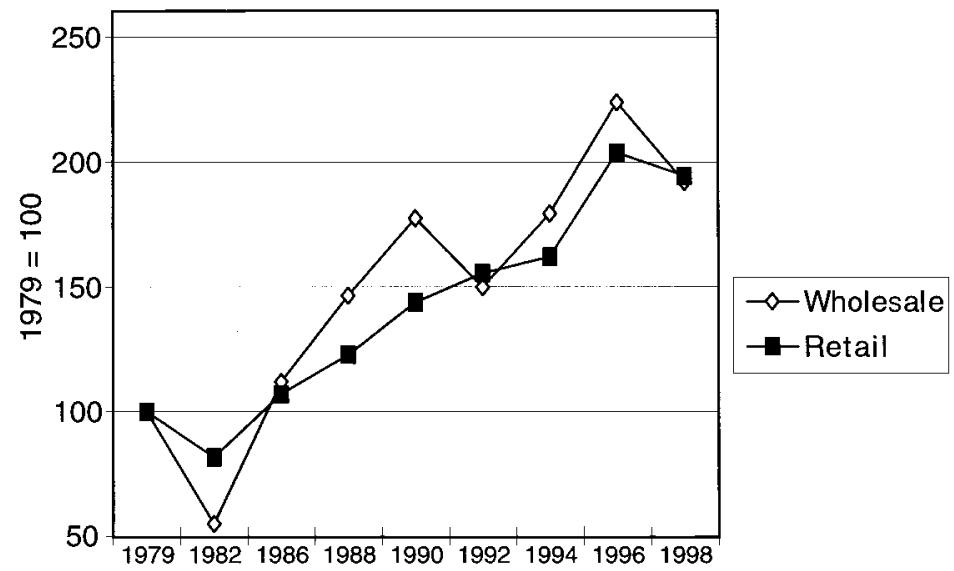

Fig. 6.3 Sales per establishment in distribution services, Korea (1979-98)

Source: See figure 6.1 note

Note: See figure 6.1 note

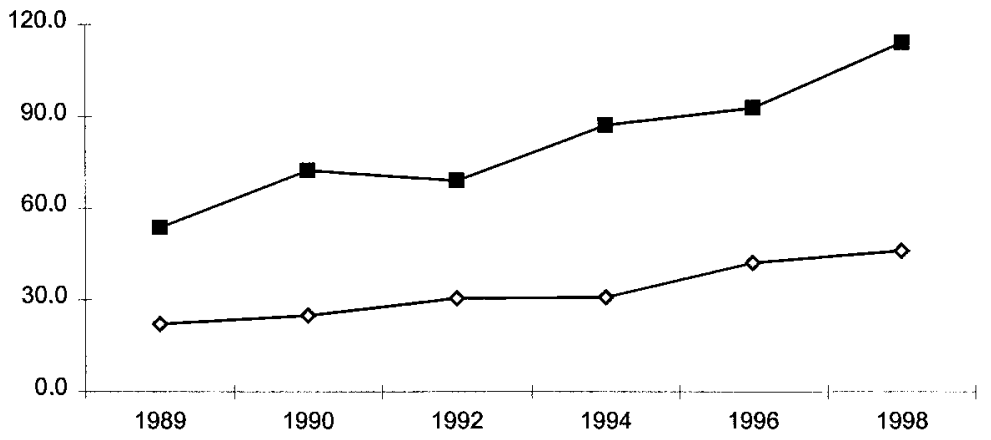

Fig. 6.4 Sales per employee in small and large-sized retail stores, Korea (1989-98)

Source: National Statistical Office, Republic of Korea, "Annual Report on the Survey of Wholesale and Retail Trade," various years.

Note: Numbers are millions of won. 
Table 6.9

Price Margin Trends for Supermarkets and Department Stores, Korea: $1995-98(\%)$

\begin{tabular}{lccccc}
\hline & 1995 & 1996 & 1997 & 1998 & Change in 1995-98 \\
\hline Supermarkets & 17.8 & 16.1 & 15.0 & 13.6 & -4.2 \\
Department stores & 24.2 & 24.8 & 22.6 & 21.7 & -2.5 \\
\hline
\end{tabular}

Source: Bank of Korea, Impact of Changes in Distribution Structure on Price Levels (26 January 2000).

by foreign firms introduced best practices management and challenged domestic retail stores. In addition, changing shopping patterns with the introduction of discount stores may have forced many small stores to specialize their services and existing domestic retail firms to enlarge their size to take advantage of the scale effect.

\subsection{Changes in Productivity Growth Rates ${ }^{5}$}

This section investigates whether the productivity changes in the service and manufacturing sectors in the 1990s were associated with services liberalization. Even though there are many problems in measuring the output of services, we follow the traditional approach by using the value added as the measure of output. The reason is as follows: first, the production of services covers a wide range of heterogeneous activities. As frequently mentioned by many authors such as Griliches (1992) and Triplett and Bosworth (2000), each service industry contains its own unique problem of measuring output, which makes a treatment applicable to all services almost impossible. Second, recent studies approach the issue with sector-specific data sets by utilizing a wide variety of methodologies. Thus, the productivity changes of different services calculated in various ways are not directly comparable. Third, unlike manufacturing, services are considerably backward in the availability of reliable data, which is particularly the case in Korea. Given the constraints of data, we simply utilize the data from national accounts as a last resort.

We first compare the level of labor productivity of the Korean service industry with that of some of the advanced countries. The growth rates of labor productivity and total factor productivity (TFP) in the Korean service sector since 1970 are then examined. Finally, we will try to see whether productivity growth in the manufacturing sector is associated with services liberalization.

\subsubsection{Sectoral Labor Productivity: An International Comparison}

In table 6.10, we compare the levels of labor productivity in Korea with those of some developed countries in 1990. Labor productivity is calculated

5. The data used for this section are described in the appendix. 
as the value added per worker. For the Group of Five (G5) countries, the value added is converted, for comparison, by using the 1985 purchasing power parity exchange rates. Because the purchasing power parity exchange rate for each sector is not available for Korea, we convert the labor productivity of Korea by using the average market exchange rate for the period 1980-90.

Table 6.10 shows that in 1990 the labor productivity of the Korean service sector, except for "utilities," was much lower than that of the United States, the European countries, and Japan. The labor productivity of "construction" and "finance, etc." in Korea was about 40 percent that of the United States. Even worse was the labor productivity of "distribution, etc." and "social services, etc.," which was 18 percent and 15 percent of U.S. levels, respectively.

\subsubsection{Productivity Growth in Services}

Table 6.11 tabulates the growth rates of labor productivity in the Korean service subsectors since 1970. "Finance, etc.," practically closed to foreign suppliers until the late 1990s, experienced the worst performance, with negative growth rates in labor productivity throughout the period, except for 1985-90. It was during this period that the Korean economy was booming with a large trade surplus. However, "distribution, etc.," which was almost completely liberalized in 1996, and "transport and communication," which was partially liberalized in the 1990s, showed increases in labor productivity in the late $1990 \mathrm{~s}$, from 5.09 percent and 0.41 percent in $1990-95$ to 7.17 percent and 1.54 percent in 1995-97, respectively.

Because labor productivity is influenced by the magnitude of capital, which is affected by FDI inflows, we next compare changes in TFP in the same period.

Total factor productivity is defined as

$$
\mathrm{TFP}=\frac{Y}{K^{\alpha} L^{1-\alpha}}
$$

where $Y, K$, and $L$ are output, capital, and labor inputs, respectively, and $\alpha$ is the elasticity of the production of capital. Thus, TFP growth is calculated as the residual of output growth net of the weighted growth of factor inputs. The underlying assumption is to use the factor shares in total costs as factor weights under constant returns to scale, Hicks neutral technical progress, and the profit maximization of firms in competitive markets. In our study, we consider two inputs, capital and labor.

It is desirable to adjust capital and labor inputs by their quality measures. However, the data on the quality of inputs at the sectoral level are not available. We use gross fixed capital stock for capital inputs and total employment for labor inputs. It is also desirable to have actually utilized 


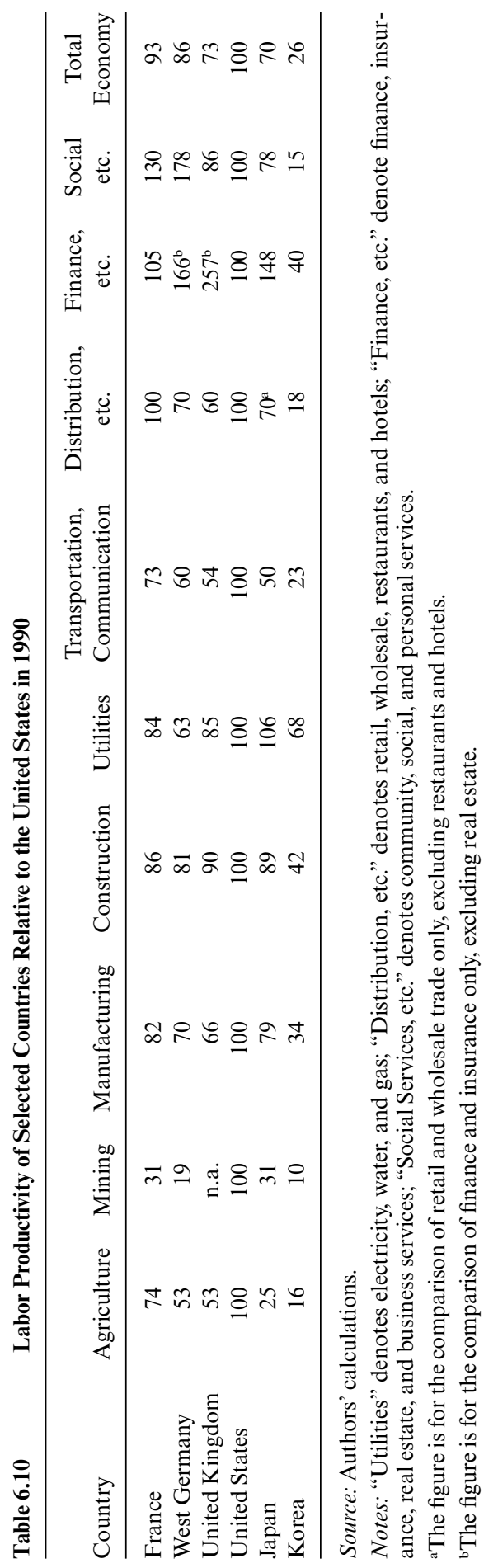




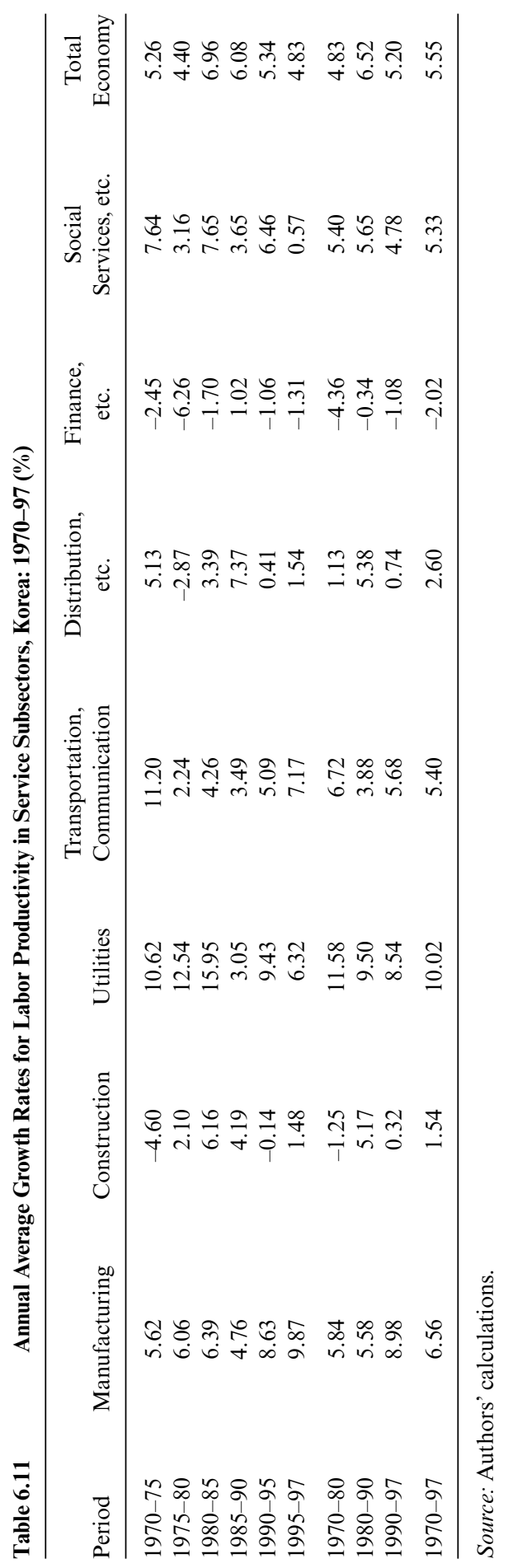


input levels by using working hours and utilized capital. However, the data on hours worked, both for capital and labor, are limited in their use for our purposes. Regarding working hours, the published data concern the hours paid rather than hours actually worked. Also, the capacity utilization rate at the subsector level is not available, particularly for the service sectors. Therefore, due to the failure to allow for cyclical variations in hours worked and capacity utilization, there is a cyclical bias to our measurements of TFP growth in the short run. However, this problem is lessened in the long run by the booms' being offset by recessions.

Table 6.12 shows that similar patterns can be detected for changes in TFP. As was the case for labor productivity, "finance, etc." recorded negative TFP growth rates throughout the period, except for 1985-90. "Transport and communications" showed a gain in TFP growth in the late 1990s, from 2.2 percent in 1990-95 to 4.12 percent in 1995-97. The trend of TFP growth in "distribution, etc." also improved in the late 1990s, from -0.41 percent in 1990-95 to -0.02 percent in 1995-97.

However, we cannot strictly prove that productivity improvement was caused by liberalization in services from the trend of labor productivity and TFP growth. As already mentioned, the two measures of efficiency considered above are subject to cyclical fluctuations, and there may be a time lag for the liberalization measure to take effect in a sector-wide productivity change. Considering that meaningful liberalization in the Korean service sectors has only been implemented since the mid-1990s, it may be too early to demonstrate any causal relationship between productivity changes and services liberalization.

\subsubsection{Contribution of Services Liberalization to Manufacturing}

The hypothesis that liberalization in services may increase the productivity of manufacturing subsectors that use liberalized services as inputs can be examined by comparing the productivity growth rates of manufacturing subsectors (table 6.13) and the input coefficients of services to those manufacturing subsectors (table 6.14).

For "nonmetals," which had a negative TFP growth rate of -0.06 percent in 1990-97, we can notice that the input coefficient of distribution services, which were liberalized in the 1990s, was 0.018 , relatively lower than the input coefficients of the other service subsectors. Thus, "nonmetals," which uses the liberalized service subsector less intensively, shows poor performance in terms of TFP growth rates when compared with other manufacturing subsectors.

However, it seems to be difficult to extract any consistent pattern from the growth rates of the TFP in the manufacturing subsectors and the input coefficients of the service subsectors. In general, the sum of the input coefficients of services in the manufacturing subsectors is in the range of 0.1 to 0.17 , which is not large enough to make a significant impact on their productivity. 


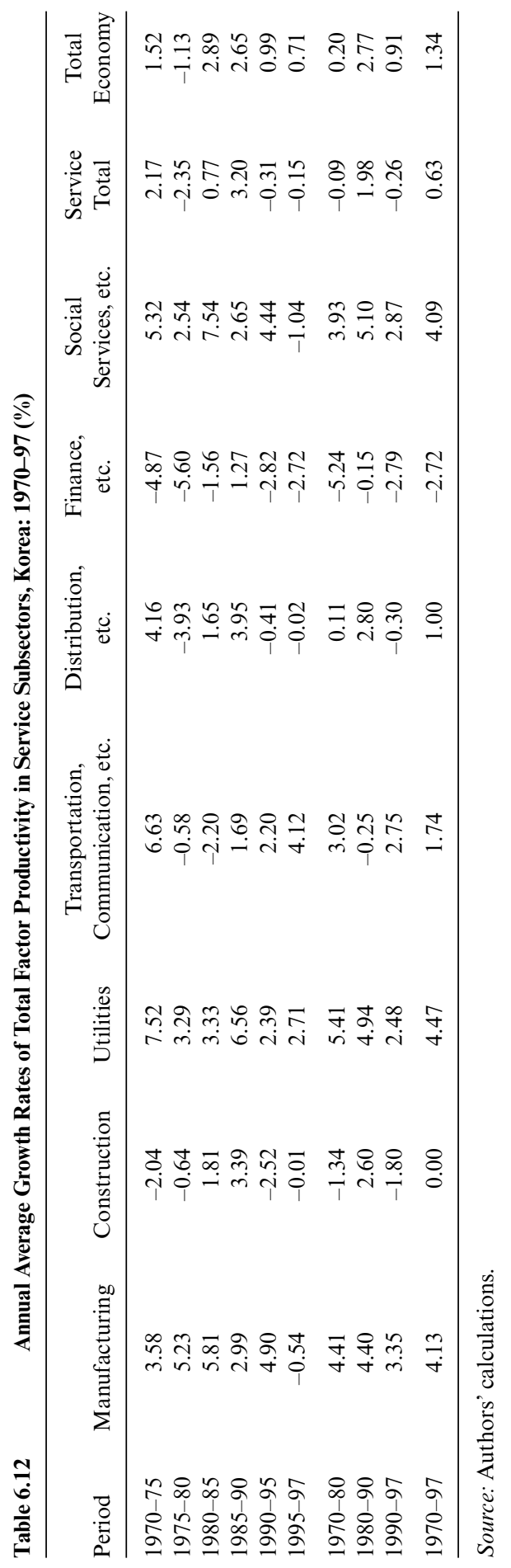




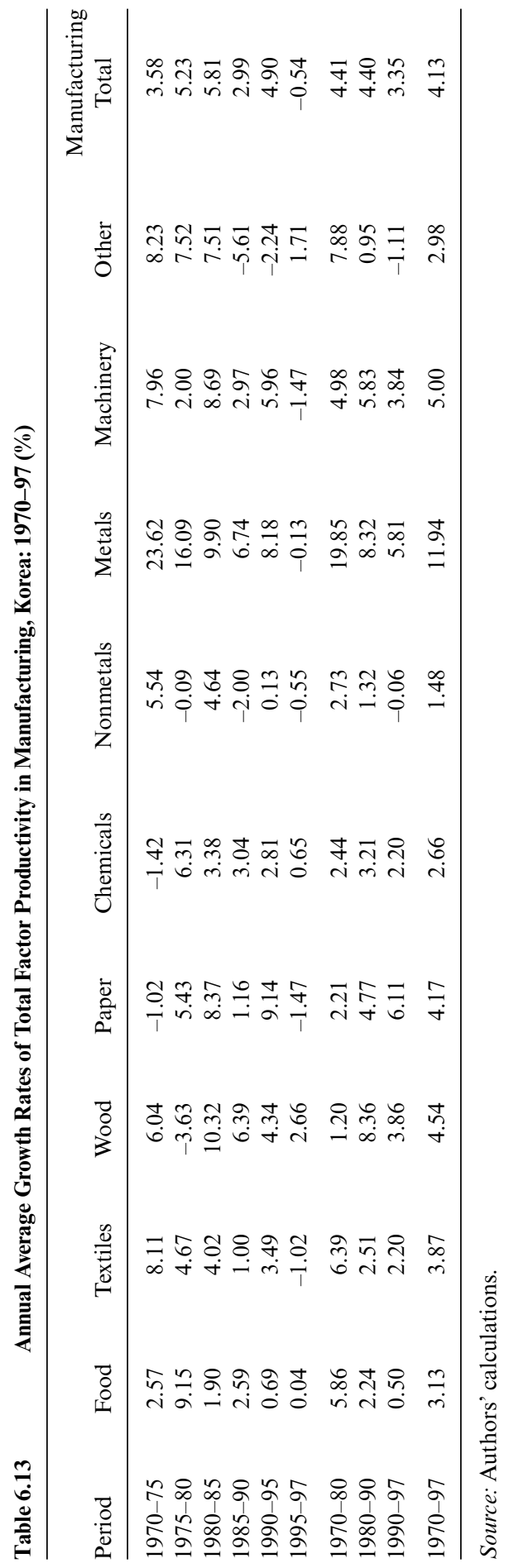




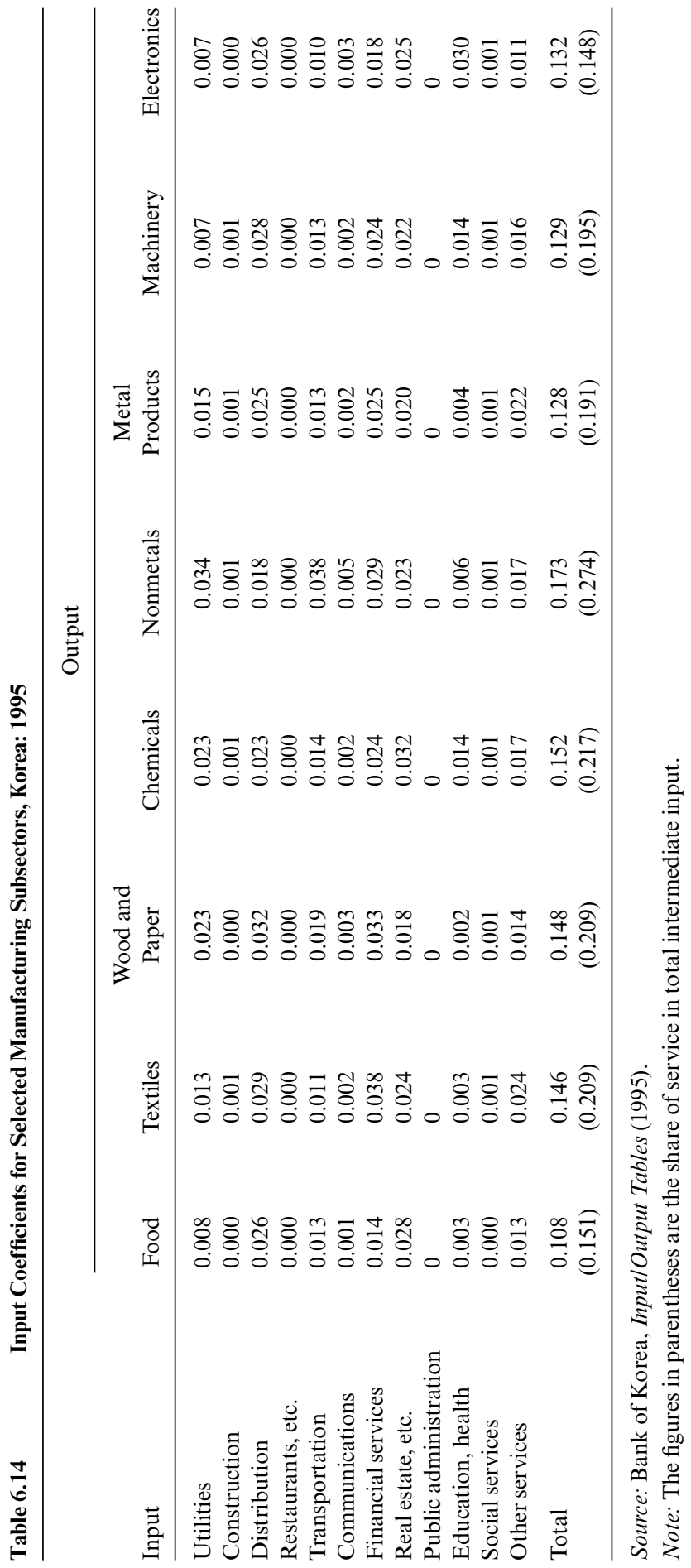




\subsection{Concluding Remarks}

Due to industrialization that gave priority to manufacturing at the expense of services, the service sector in Korea was grossly underdeveloped prior to the early 1990s. Numerous sector-specific regulations and restrictions on FDI prevented competition and impeded the offering of highervalue services. In 1990, the labor productivity of the Korean service subsectors was much lower than that of the advanced countries. The labor productivity of "distribution services, etc.," in particular, was less than onefifth that of the United States in 1990.

Since the mid-1990s, the Uruguay Round negotiations and accession to the OECD enabled the Korean government to gradually open the service sector to foreign suppliers. The financial crisis of late 1997 resulted in the Korean service sector's becoming almost completely open, except for a few areas sensitive to national security, culture, and political stability.

The liberalization of services is presumed to bring productivity gains in the service sector and also in manufacturing sectors that use liberalized services as inputs. In searching for some evidence of this in Korea, we examined the changes in productivity of the service and manufacturing subsectors in 197097. Because liberalization took place in the 1990s and it takes time to see the full effects of liberalization, it is too early to give a definite answer to whether liberalization in services has caused an increase in productivity in Korea. However, we see a productivity improvement in such sectors as distribution services, which had a large inflow of FDI due to liberalization in the 1990s.

\section{Appendix}

\section{Sources of Data}

The sectors considered were selected on the basis of their availability for output and factor use. The sector classification used was the International Standard Industrial Classification System. Output was measured as value added in constant prices, the data for which were obtained from the national accounts of Korea collected by the Bank of Korea.

The labor input is measured as total employment. The Annual Report on the Economically Active Population Survey (AREAPS) provides the data on total employment. However, AREAPS does not classify most of the service subsectors for periods earlier than $1991 .{ }^{6}$ Thus, we computed the ratio for each service subsector based on the data from the Statistical Yearbook of the International Labor Organization (ILO) and the employment tables

6. The Annual Report on the Economically Active Population Survey currently classifies service sectors as electricity, gas, and water; retail and wholesale trade, restaurants, and hotels; transport, storage, and communications; financial institutions, insurance, real estate, and business services; and community, social, and personal services. 
of the Bank of Korea and estimated the total employment for each subsector by applying the computed ratio to the total employment of the service sector of AREAPS.

Capital input is defined as gross fixed capital stock and was computed by applying the perpetual inventory method (PIM) to the data on the gross fixed capital formation of each industry in constant prices obtained from the national accounts. To use the PIM, we need data on benchmark capital stock and the depreciation rate. However, reliable data on these two variables are not available. Therefore, we extrapolated the gross fixed capital formation back to 1930 based on the time trend from 1953 to 1960 to avoid the problem of benchmark capital stock and accumulated the investment from $1930 .{ }^{7}$ For the depreciation rate for each industry, we used the average rates of the corresponding Japanese industries, calculated from the International Sectoral Database (ISDB) published by the OECD, under the assumption that the structure of the Korean economy is most similar to Japan among the developed countries covered by the ISDB.

Finally, to compute the TFP, we need data on the share of labor in value added. The labor share is calculated by dividing the compensation of labor by value added. Because the data on the compensation of employees from the national accounts do not include the compensation of self-employed labor, we adjusted the compensation of employees under the assumption that the compensation of the self-employed is comparable to that of the employed. That is,

The share of labor in value added $=$ (compensation of employees

+ [compensation of employees/total employees]

$\times$ [total employment - total employees])/value added.

The data on the compensation of employees and current value added are taken from the National Accounts. The number of total employees is taken from the ILO Statistical Yearbook and the employment tables of the Bank of Korea. The share of agriculture and fisheries; community, social, and personal services; retail and wholesale trade; and restaurants and hotels, computed as above, are too high. The employment in these industries shows that a large proportion of unpaid family workers may be underemployed. Thus, when comparing them with some of the advanced countries from the ISDB, we assumed that the unpaid workers were compensated at half the rate of paid workers. After adjustment, the shares of labor in value added for these industries were comparable to the estimate of Kim and Park (1985).

Finally, the data on some of the advanced countries used for international comparison were taken from the ISDB of the OECD, which provides sectoral output and input data of OECD countries from 1970 to 1990. 


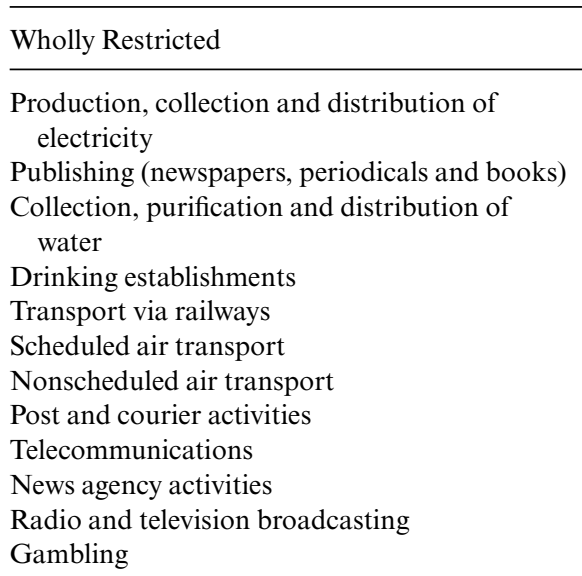

Partially Restricted

Wholesale of agricultural raw materials, live animals, food, beverages and tobacco

Wholesale of household goods (medical goods and cosmetics)

Wholesale of nonagricultural intermediate products, waste and scrap (fertilizers)

Other wholesale (foreign trade brokers)

Retail sale of food, beverages and tobacco in specialized stores

Other retail trade of new goods in specialized stores

Land transport

Sea and coastal water transport

Inland water transport

Travel agencies

General financial intermediation (banking)

Other financial intermediation (investment, trust, securities)

Insurance and pension funding

Real estate rental and development

Renting of other machinery and equipment (construction equipment)

Research and experimental development on social sciences and humanities

Legal, accounting, bookkeeping and auditing activities; tax consultancy; market research and public opinion polling; business and management consultancy

Advertising

Other business services (personnel supply services, investigation and security activities)

Adult and other education (vocational training schools, etc.)

Human health activities

Veterinary activities

Motion pictures and other entertainment activities

Libraries, archives, museums and other cultural activities

Sporting and other recreational activities

Other service activities (barber and beauty shops, wedding chapels, etc.)

Other recreational activities (parks, beaches, etc.)

Personal services (tutoring, housekeeping, etc.)

Source: Ministry of Finance and Economy, Five-Year Foreign Investment Liberalization Plan (various years)

Note: In KSIC three-digit level. 
Table 6A.2

Service Subsectors in which FDI is Restricted (as of November 1997)

\begin{tabular}{|c|c|}
\hline Wholly Restricted & Partially Restricted \\
\hline $\begin{array}{l}\text { Collection, purification and distribution of } \\
\text { water } \\
\text { News agency activities } \\
\text { Radio and television broadcasting } \\
\text { Gambling }\end{array}$ & $\begin{array}{l}\text { Wholesale of agricultural raw materials, live } \\
\text { animals, food, beverages and tobacco } \\
\text { (meat) } \\
\text { Production, collection and distribution of } \\
\text { electricity } \\
\text { Publishing (newspapers, periodical and } \\
\text { books) } \\
\text { Other retail trade of new goods in } \\
\text { specialized stores (gas stations) } \\
\text { Land transport } \\
\text { Sea and coastal water transport } \\
\text { Scheduled air transport } \\
\text { Nonscheduled air transport } \\
\text { Telecommunications } \\
\text { General financial intermediation (banking) } \\
\text { Other financial intermediation (investment, } \\
\text { trust, securities) } \\
\text { Insurance and pension funding } \\
\text { Real estate rental and development } \\
\text { Credit information agency }\end{array}$ \\
\hline
\end{tabular}

Source: Ministry of Finance and Economy, Five-Year Foreign Investment Liberalization Plan (various years).

Note: In KSCI three-digit level.

\section{References}

Anwar, Syed Tariq, and Michael A. Taku. 1993. Productivity and efficiency in the Japanese distribution system: A review and developments. Journal of World Trade 27:83-110.

Blomstrom, Magnus, and Hakan Persson. 1983. Foreign investment and spillover efficiency in an underdeveloped economy: Evidence from the Mexican manufacturing industry. World Development 11:493-501.

Borensztein, E., J. de Gregorio, and J. W. Lee. 1998. How does foreign direct investment affect economic growth? Journal of International Economics 45:115-35.

Caves, Richard E. 1974. Multinational firms, competition, and productivity in hostcountry markets. Economica 41:176-93.

Chung, W., W. Mitchell, and Bernard Yeung. 1994. Foreign direct investment and host country productivity: The case of the American automotive components industry. Discussion Paper no. 367. University of Michigan, Institute of Public Policy Studies.

Globerman, Steve. 1979. Foreign direct investment and "spillover" efficiency benefits in Canadian manufacturing industries. Canadian Journal of Economics 12: 42-56.

Griliches, Zvi. 1992. Introduction. In Output measurement in the service sectors, ed. Zvi Griliches, Chicago: University of Chicago Press.

Ito, Takatoshi, and Masayoshi Maruyama. 1991. Is the Japanese distribution sys- 
tem really inefficient? In Trade with Japan, ed. Paul Krugman, Chicago: University of Chicago Press.

Kim, J.-D., and S.-I. Hwang. 2000. The role of foreign direct investment in Korea's economic development: Productivity effects and implications for the currency crisis. In The role of foreign direct investment in East Asian economic development, ed. Anne O. Krueger and Takatoshi Ito, 267-94. Chicago: University of Chicago Press.

Kim, K.-S., and J.-K. Park. 1985. Sources of economic growth in Korea: 1963-1982. Seoul: Korea Development Institute.

Markusen, James R. 1989. Trade in producer services and in other specialized intermediate inputs. American Economic Review 79:85-95.

McKinsey Global Institute. 1998. Productivity-led growth for Korea. Washington, D.C.: McKinsey Global Institute.

Nickell, Stephen J. 1996. Competition and corporate performance. Journal of Political Economy 104:724-46.

Rivera-Batiz, Francisco L., and Luis A. Rivera-Batiz. 1992. Europe 1992 and the liberalization of direct investment flows: Services versus manufacturing. International Economic Journal 6:45-57.

Triplett, Jack E., and Barry P. Bosworth. 2000. Productivity in the service sector. Washington, D.C.: Brookings Institution. Manuscript.

\section{Comment Kazumasa Iwata}

The paper investigates the impacts of service liberalization, notably establishment trade through commercial presence, on productivity in Korea. The authors found it premature to show empirical evidence on an increase in productivity. They argue, however, that competition is enhanced, notably in the distribution sector, which may lead to an increase in productivity.

The liberalization of services trade may increase productivity through a number of channels. First, the establishment trade via commercial presence brings about an increase in production and in management know-how and imparts a productivity spillover effect to the economy.

Second, the improved quality and diversified service with lower prices as intermediate inputs (both embodied and disembodied) may improve the productivity of the manufacturing sector. This constitutes the major source of benefit of developing countries that have a comparative disadvantage in service trade.

Third, the liberalization of trade in services may enhance competition. This implies that trade liberalization affects the market structure in an economy. Although it does not exclude the case of foreign monopoly, the Korean economy seems to prove that the domestic economy is large enough to permit the commercial presence of foreign firms. We should recall that some

Kazumasa Iwata is a professor of economics at the University of Tokyo. 
developing economies have employed trade restriction as the imperfect substitute for antimonopoly law.

Fourth, the transmission of advanced knowledge through the joint research and development and provision of licenses constitutes the channelof-productivity increase.

It is interesting to observe that in the case of Korea the establishment trade in services has accelerated after the financial crisis, despite the fact that the massive inflow and subsequent outflow of capital disrupted the financial market. It seems important to pay due attention to the fact that the financial liberalization has been accompanied by over-investment by nonfinancial firms and constituted the precondition to financial crisis. The absence of appropriate prudential policy on financial institutions' financial trade liberalization may have had a destabilizing effect on the economy. The financial disruption seemed to work to deepen the recession.

Table 6.9 provides an international comparison of sectoral labor productivity in 1990, whereas table 6.11 provides an interesting result on changes in total factor productivity (TFP). It indicates an improvement of productivity in the service sector, notably in the transport and communication sector, in 1995-97, despite the recession. However, it is somewhat puzzling that productivity in the financial sector registered a negative rate of increase for a long period of time, from 1970 to 1997. Further, I find it difficult to accept the statement that the distribution sector shows an improvement in productivity when I look at tables 6.10 and 6.11; the negative TFP growth is recorded in 1995-97. In contrast, figure 6.1 points to an increase in sales per employee, but it is not clear whether it implies a productivity gain. It seems necessary to provide additional evidence to confirm the productivity improvement in the distribution sector after 1996.

My first comment is whether the productivity gain is attributable solely to foreign direct investment. I suspect that domestic regulatory reform in the communication sector, in addition to the distribution sector, may have played an important role in increasing the productivity of almost all service sectors. Liberalization of trade in service often takes place simultaneously with domestic regulatory reform. Both promote competition and efficiency in an economy. It is important to discriminate between the effects of reduction in the domestic distortion and in the external distortion. Apparently, services trade liberalization deals with the latter. It seems possible to truncate the impact by employing some econometric methods, although note 2 mentions that it is difficult to differentiate between the impacts of domestic deregulation and external liberalization.

For instance, it may be useful to apply the tariffication to trade in services, as argued by Deardorff (2000), or develop the tax-equivalent measures in assessing external distortion, such as the exercise carried out by the Australian Productivity Council. 
My second comment is a question as to whether the observed productivity gain is due to the expansion of the production frontier or the shift of the production point inside the existing production frontier to the more efficient point.

Foreign direct investment (FDI) implies an increase in capital accumulation, coupled with transfer of management and reduction in external distortion, whereas domestic deregulation simply removes barriers and reduces domestic distortion. Thus, the increase in FDI is accompanied by the expansion of production frontiers into the direction that the Rybczynski theorem predicts. The lack of appropriate data may prevent judgment. However, it may be useful to delineate the difference, at least conceptually, because it relates to the issue on the order of liberalization, notably with respect to financial liberalization.

Third, I would like to know why the intermediate service inputs in total intermediate inputs take on such a small share (0.15-0.17) in intermediate inputs of the Korean manufacturing sector. In Japan the share ranges from 0.28 to 0.3 in 1995, whereas in the United States it is 0.32 in 1990. As is shown by the simulation results in a paper presented at this conference by Kun-Ming Chen and others (chap. 4 in this volume), the service inputs are important not only for the development of the service sector but also for strengthening the competitiveness of the manufacturing sector. The smaller share of intermediate service inputs implies a smaller impact (about half) of liberalization of trade in services in the case of Korea, as compared with other countries, such as Japan and the United States.

Fourth, the paper primarily concerns productivity. However, the benefit for consumers appears mainly through price reduction and diversification of services. The price differential between home and abroad and the comparison of cost structures provide additional information on domestic and external distortion. It may be promising to employ cost function, instead of production function, in continuing the analysis on changes in consumer welfare by the liberalization of trade in services.

Fifth, despite the difficulty in the case of abnormal shocks like financial crises, it still seems important to make some cyclical adjustment to the labor and total productivity changes, in order to assess the impact of liberalization.

Finally, with respect to productivity changes in distribution sector, I find it more important to pay attention to the impact of information and telecommunication innovation due to the regulatory reform; it contributes to the expansion of production frontier due to the new innovation and the network externality effect. It may be noted that in the case of Japan the large retail stores like Ito-Yokado intend to make new entry into banking business specializing in payment services by utilizing both the physical and virtual networks. Conversely, many banks attempt to enclose networks of con- 
venience stores. This attempt can enhance competition and bring about an increase in productivity in financial service.

\section{Reference}

Deardorff, A. V. 2000. Tariffication of services. Paper presented at the conference organized by Keio University. 19 May.

\section{Comment Mahani Zainal-Abidin}

The paper shows that Korea's service sector liberalization began in the early 1990s with its commitment to the Uruguay Round negotiation and later membership to the Organization for Economic Cooperation and Development (OECD). The pace of liberalization was further accelerated during the East Asian Crisis, and by May 2000 only very few service industries had total or partial restrictions (see table 6.2).

The paper suggests that liberalization of Korea's service sector, which allows for greater participation of foreign direct investment (FDI), will improve productivity of liberalized service subsectors as well as of the manufacturing sector that uses the services of these subsectors.

My comments are as follows.

First, the main channel for productivity improvement put forward in this paper is through higher participation of FDI that can inject technology transfer and overcome economies of scale constraints. Increasing foreign participation is one form of service sector liberalization. An equally important form of liberalization concerns domestic service producers, namely, the lowering of barriers to domestic producers through deregulation and dismantling of regulatory impediments. These may take the form of what is called in Kim's paper barriers to ongoing operation or barriers that are designed to protect incumbent firms.

The paper should describe more the measures of liberalization for domestic service producers - for example, to what extent the Korean services liberalization has removed entry and competition barriers. In other words, to what extent is productivity improvement in the service subsector due to the removal of barriers to ongoing operation of domestic services providers vis-à-vis increased FDI participation?

For example, in Malaysia, productivity gains in service subsectors such as telecommunications are substantially caused by deregulation of domes- 
tic industries through increasing the number of participants and competition in the industry.

Another form of services liberalization is through privatization. Most of the services industries are publicly owned, and privatization of these activities since the late 1980s has allowed these services to be managed in a more efficient manner and has made cost and quality of service key in evaluating their performance. As a result, there was a marked increase in the productivity of these privatized services. For example, parts of the health, education, and water sectors have been privatized, and the ensuing higher productivity has benefited consumers and has attracted investments in these sectors.

Second, I would like to comment on the calculation of service subsector productivity.

The key problem in calculating service productivity is in determining a suitable measure of output over time. This is complicated by two factors: a) market prices may not be observable for publicly provided services, and b) it is often difficult to identify precisely what constitutes a service activity in a particular industry and to account correctly for quality changes in services.

The measurement of output requires identifying whether the output consists of the transaction performed or the outcome achieved through the service. A case in point is the finance subsector. The subsector experienced negative growth rates in labor productivity throughout the 1970-97 period, except for 1985-90. The period 1985-90, in which productivity rose substantially, was when the Korean economy boomed following the 1988 Olympic games. Thus, the increase in output of finance subsector was due to bigger transaction volume and not improvement in services. Further, the finance sector offers a variety of activities that may increase its output (revenue) by expanding the scope of financial transactions, and this higher revenue may not come from improvement in service.

The measurement difficulties are further aggravated by contributions made by technology. In some services, such as distribution, telecommunication, and parts of the financial service industry, technological change has strongly affected the production process and the organization of production. This has contributed to significant improvements in productivity, but this may not always be easy to measure.

To overcome these measurement problems, some studies have used the growth rate of capital as a proxy for services output growth.

Third, I would like to comment on the contribution of services liberalization to the manufacturing sector.

The paper has produced two interesting tables: table 6.8 , on annual average growth rates of total factor productivity in the manufacturing sector, and table 6.9, on input coefficients for selected manufacturing subsectors. As contended by the paper, liberalization in service subsectors will benefit 
the manufacturing industries that use the services of these subsectors through productivity improvements. The paper should explore and formalize these links. These two tables have given the authors a good start, and this work should be expanded to capture the links between service subsectors and manufacturing industries.

Finally, the authors should be commended for initiating a study to estimate productivity improvements in the service sectors, especially for the distribution industry. 
